\title{
An Honest Conversation: An In-Class Tool to Help Pre-Law Students Determine Their Compatibility with Law School and a Legal Career
}

Justin Gollob, Colorado Mesa University

ABSTRACT At a time when a single semester oflaw school can be a significant financial investment, the decision to attend law school should not be made casually. Instead, decisions should be influenced by data, reflection, and an understanding of real-world outcomes. In this article, I present The Legal Career Compatibility Project; a tool to help students make an informed decision about pursuing a career in law. Using Bolles (2003), Phases 1 and 2 help prospective law students determine whether they should pursue a legal career. Phase 3 helps students determine where and how to apply to law school. Considering that the odds of gaining admission to law school are high, conversations about whether one should attend law school are equally, if not more, important than conversations about how to gain admission. The purpose of the project is to influence how decisions to attend law school are made, not to encourage or discourage students from a career in law.

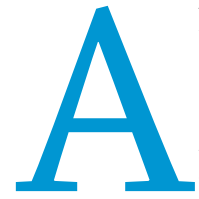

lthough law schools accept students from every academic discipline, political science is the most common major among law school applicants. According to data supplied by LSAC (2016), 12,693 political science majors applied for admission to law school in $2015^{-16}$, comprising $18.1 \%$ of all applicants. By comparison, the defined field of study with the second most applicants-criminal justice-saw 3,857 majors apply to law school, comprising $5.5 \%$ of all applicants. The good news is that a majority (81.4\%) of political science majors were admitted to law school.

The bad news is that law graduates will face a challenging employment market. According to Campos (2012), "only about half of current law school graduates are acquiring jobs as lawyers, even if we define what counts as working as a lawyer in the most generous possible terms" (xiii). Employment data provided by the American Bar Association shows that just $62.4 \%$ of graduates from the class of 2015 were employed in jobs where bar passage was required (ABA 2017). Moreover, as the cost of earning a law degree has increased, so has the debt incurred to finance it.

For some, the benefits of earning a law degree will outweigh the costs. For others, the opposite will be true. In what follows, I present a tool to help students determine their compatibility

Justin Gollob is an associate professor of political science at Colorado Mesa University. He can be reached at jgollob@coloradomesa.edu. with a legal career through self-reflection and data analysis. ${ }^{1}$ This three-piece tool begins with an introspective exercise that helps students identify attributes of their ideal job, determines how well those attributes match careers in law, and helps students determine where and how to apply to law schools that will lead to their ideal job. This tool can be used in pieces for individual advising sessions, or it can be used to structure an entire course.

\section{A CHALLENGING ENVIRONMENT}

The cost-benefit calculation of pursuing a law degree is complicated. When considering the cost side of the calculation, one thing stands out; a law degree is not a sure financial bet. According to Tamanaha (2012), "the cost of a legal education today is substantially out of proportion to the economic opportunities obtained by the majority of graduates" (x). Indeed, in recent decades, law school tuition has risen significantly. Barton (2015) calculates that "between 1985 and 2009, law school tuition rose 820 percent for in-state residents at public institutions and 375 percent at private institutions" (139). As a result, debt has increased for law graduates. For example, "in just the last eleven years the average amount of law school debt rose from $\$ 46,499$ to $\$ 84,600$ at public schools and from $\$ 70,147$ to a whopping $\$ 122,158$ at private law schools" (139).

Tamanaha (2012) points to several causes for tuition increases, such as the cost of maintaining an elite faculty, decreased state 
funding to public law schools, increased costs for supplying and supporting information technology, and costs associated with subsidizing faculty research. Regardless of the causes, the reality is that just a single semester of law school can cost tens of thousands of dollars. This means that even a short experiment with law school can be a very expensive proposition.

While the costs of earning a law degree are increasing, for some, the benefits are decreasing. There are several reasons why the employment picture for many law graduates is challenging. First, salaries for many law graduates are flat or lower than in the past. Examining full-time salary statistics for the class of 2011, Barton (2015) illustrates that salaries generally fall into one of two buckets: (1) six-figure salaries $(\$ 160,000)$ for lawyers generally working in elite law firms, and (2) five-figure salaries $(\$ 35,000-\$ 65,000)$ for graduates generally working outside of elite law firms. ${ }^{2}$ The reality is that most lawyers practice in bucket 2 and that wages in bucket 2 have "either held steady or declined over the last forty years, with wages for solo practitioners seeing a 34 percent decline in real dollars over that period" (46). For the class of 2014, full-time "jobs paying $\$ 160$,ooo accounted for about $17 \%$ of reported salaries, while jobs paying $\$ 40,000-65,000 \ldots$ accounted for about half of reported salaries" (NALP 2015). about students' desires to attend law school by helping them assess their compatibility with real world outcomes. In short, the purpose of the project is to help students make the best decision for themselves. The project is divided into three phases: (1) Inventory, (2) Matching, and (3) Planning.

The "Inventory" phase, presented in Appendix 1, helps students identify attributes of their ideal job by completing The Flower Exercise published in "What Color is Your Parachute?" (Bolles 2003). ${ }^{6}$ In this intensive step-by-step exercise, students first identified and rank ordered their favorite skills (e.g., "keeping records") by writing and analyzing stories about their lives. After identifying their favorite skills, students then completed short exercises addressing: geography; interests; people environments; values, purposes, and goals; working conditions; and salary and level of responsibility (Bolles 2003).7 At the conclusion of the Flower Exercise, students had a much better vision of their ideal job. ${ }^{8}$ One student commented that while "the flower diagram may have seemed a little silly at first ... it was one of the most helpful aspects of this project." Another student stated that this exercise "was incredibly useful for getting the conversation started, as it uncovered what our real interest in the law was."

With the attributes of an ideal job in mind, the "Matching" phase of the project required students to determine how well a

\section{For the class of 2014, full-time "jobs paying $\$ 160$, ooo accounted for about $17 \%$ of reported salaries, while jobs paying $\$ 40,000-65,000$... accounted for about half of reported salaries" (NALP 2015).}

The second reason for a complex employment picture is that law schools are producing a lot of lawyers. According to Campos (2012), "for decades now, law schools have produced far more aspiring lawyers than there are jobs for attorneys-and this mismatch between supply and demand is getting worse all the time" (1). This is supported by data showing that "in 1930, there was roughly 1 lawyer for every 885 Americans. By 1950, it was 1 to 687 and by 2011, it was 1 to 254 " (Barton 2015, 34).

Finally, significant changes to the legal environment have introduced new stresses for law graduates. As detailed by Barton (2015), the boom times for Big Law have slowed and solo practitioners and small firms are facing significant competition. This increased level of competition is the result of many factors, including more lawyers competing for business as well as technological advances in how services are delivered.

\section{THE LEGAL CAREER COMPATIBILITY PROJECT}

Given these challenges, I created a tool to help students measure their compatibility with a legal career. The decision to attend law school should not be made casually; instead, the decision should be guided by data and an understanding-and acceptance-of real world outcomes and costs. This tool was administered to students enrolled in an upper-division pre-law course at my home institution. The content for this class was a mixture of traditional law and society courses and pre-law studies courses. The first half of the course covered topics typically discussed in law and society courses. ${ }^{4}$ The second half of the course examined the evolution, and current state, of the legal field. 5

The centerpiece of this course was the "Legal Career Compatibility Project." This project structured an honest conversation career in law aligns with their vision of an ideal job. As detailed in Appendix 2, I asked students to identify an area of law they would be interested in practicing by reading 24 Hours with 24 Lawyers (Kim 2011). When reading the book, students identified which of the 24 lawyers' experiences best matched their own interests and values, purposes, and goals as identified in Phase 1. They then researched how well different legal careers (e.g., solo practice, big law, public interest) aligned with their favorite skills, working conditions, and people environment as determined in The Flower Exercise. Finally, students researched the occupational outlook for their specific career in their preferred geography to calculate employment prospects and salary levels.

The results from each "petal" in The Flower Exercise were used to determine how well the actual practice of law aligned with their ideal job. A critical point is that I required data, not just vague pronouncements in each phase of the project. For example, when calculating employment prospects, students were required to search for job listings that matched their ideal legal career in their ideal geography. As a result, some students were disappointed to find that, for example, the job market for international lawyers in Denver, Colorado, is not particularly strong.

After students identified their attributes of an ideal job in Phase 1 and determined how well a career in law aligned with their ideal job in Phase 2, they then sketched a plan to pursue that career in Phase 3-"Planning." One student described this phase as "a wake-up call...where we were confronted with the rigors of getting into law school." As detailed in Appendix 3, students identified law schools that matched the results of phases 1 and 2. Students researched real-world outcomes for recent graduates such as bar examination pass rates, employment rates, salary 
statistics, and geographic residence. They were also required to submit a cost evaluation of attending their preferred law school, including monthly repayment costs for their anticipated loan amount, as well as competitive GPAs and LSAT scores for admission.

With those statistics in mind, students completed a full-length LSAT practice test and calculated their probability of being accepted into their top two law schools. If their probability was low, they were required to submit a plan of action to correct any deficient scores. program, this pairing would result in a 6-credit course -3 credits for the course and 3 credits for an internship. This addition will allow students the opportunity to supplement course material through experiential learning.

\section{SUPPLEMENTARY MATERIAL}

To view supplementary material for this article, please visit https://doi.org/10.1017/S1049096517001937

\section{...the purpose of this exercise is not to lock students into specific legal careers, but to highlight the reality of what it means to pursue a career in law.}

Students then submitted a calendar listing critical deadlines and drafted a personal statement for my feedback. At the conclusion of Phase 3 , students had developed a plan of action. While the workload was significant, students appreciated that Phase 3 "got the ball rolling" on their application preparation and opened their eyes to the application process. One student wrote, "I do not come from a family of lawyers or [know] anyone who has gone through this experience, so I had no idea what I was getting myself into when I decided I wanted to go to law school. I think it will be very helpful for me come this fall when I begin this process, so I am not blindsided or overwhelmed by the amount of work it is."

As for the value of this project, one student said, "the legal career compatibility [project] was essential in helping me decide whether or not I wanted to pursue a career as a lawyer." Another student said, "I would definitely recommend this . . . project to anyone who is questioning law school, [and] even those who are positive law school is in their future." Students also discussed the Legal Career Compatibility Project's usefulness in helping them decide on attending law school. One student said, "this was a great learning tool for me and out of it I learned that law school is not for me, at least not yet." However, another student found that "each of the phases were instrumental in helping me come to the decision that I do want to go to law school [and] become a lawyer." The true value of this project is best illustrated by a quote from a student who said that "no matter what the outcome of the project was, the decision was thoroughly considered."

\section{LIMITATIONS AND NEXT STEPS}

While the Legal Career Compatibility Project can help students determine their compatibility with a legal career, there are some limitations. In particular, one criticism of this exercise is that it requires students to know more about the legal field than they can possibly understand as undergraduate students. For example, how can a junior level political science major select an area of law to practice when they have never taken an actual class in law school? While I agree with this critique, the purpose of this exercise is not to lock students into specific legal careers, but to highlight the reality of what it means to pursue a career in law. In short, this exercise helps students determine their compatibility with a career in law; it does not cement their place in the legal field. Moreover, this exercise can be repeated, as a whole or piecemeal, as students narrow their focus in law school.

Plans for future iterations are to add an internship, either as an option or as a requirement, to the course. Modeling this after Temple University's political science experiential learning

\section{ACKNOWLEDGMENTS}

I would like to thank Dr. Bill Flanik and Dr. Michael Delaney for their assistance.

\section{NOTES}

1. For a discussion of the role of reflection in learning see Fink (2013).

2. Based on self-reported salaries of 18,630 2011 law school graduates.

3. Barton (2015) discusses these and other challenges as the "four deaths the legal profession now faces." These challenges are detailed in chapters $2-7$.

4. Books assigned for the first half of the course include Feinman (2014) and Moliterno and Lederer (2010).

5. Books assigned for the second half of the course include Kim (2011) and Levine (2011).

6. There are changes to the Flower Project across the many editions of this book. You may need to make minor (e.g., ordering of petals) changes to the Legal Career Compatibility Project depending on which edition you select.

7. The overall category of working conditions measures "Under what circumstances do you do your most effective work?" (Bolles 2003).

8. I had two concerns in assigning The Flower Exercise. First, not everyone is open to self-help books, and my concern was that some students may not take the exercise seriously. The second complication deals with embarrassment. For example, when calculating their desired salary, students had to complete a monthly budget. To address these concerns, please reference the instructions for Phase 1 located in the appendix.

\section{REFERENCES}

ABA. 2017. “2015 Law Graduate Employment Data.” http://www.americanbar.org/ content/dam/aba/administrative/legal_education_and_admissions_to_the_bar/ reports/2015_law_graduate_employment_data.authcheckdam.pdf.

Barton, Benjamin H. 2015. Glass Half Full: The Decline and Rebirth of the Legal Profession. Oxford: Oxford University Press.

Bolles, Richard Nelson. 2003. What Color is Your Parachute? 2003: A Practical Manual for Job-Hunters and Career-Changers. Berkely, CA: Ten Speed Press.

Campos, Paul. 2012. Don't Go to Law School (Unless): A Law Professor's Inside Guide to Maximizing Opportunity and Minimizing Risk. United States: CreateSpace.

Feinman, Jay M. 2014. Law 101: Everything You Need to Know About the American Legal System, 4th ed. Oxford: Oxford University Press.

Fink, L. Dee. 2013. Creating Significant Learning Experiences: An Integrated Approach to Designing College Courses. San Francisco: Jossey-Bass.

Kim, Jasper. 2011. 24 Hours with 24 Lawyers: Profiles of Traditional and Non-Traditional Careers. United States: Aspatore.

Levine, Ann. 2011. The Law School Decision Game: A Playbook for Prospective Lawyers Santa Barbara, CA: Abraham Publishing.

LSAC. 2016. "Undergraduate Majors of Applicants to ABA-Approved Law Schools." http://www.lsac.org/docs/default-source/data-(lsac-resources)docs/2015-16_applicants-major.pdf.

Moliterno, James E., and Fredric Ira Lederer. 2010. An Introduction To Law, Law Study, And The Lawyer's Role. 3rd ed. Durham, NC: Carolina Academic Press.

NALP. 2015. "Class of 2014 Bimodal Salary Curve." http://www.nalp.org/class_ of_2014_salary_curve.

Tamanaha, Brian Z. 2012. Failing Law Schools. Chicago: The University of Chicago Press. 